\title{
The Effectiveness of The Implementation of SPIP and SIMDA Its Impact Against The Quality of Financial Statements
}

\author{
Galih Raspati $^{1}$, Andi Riyanto ${ }^{2}$ \\ ${ }^{1}$ STIE Pasim Sukabumi, galih_raspati@yahoo.com \\ ${ }^{2}$ Bina Sarana Informatika University, andi.iio@bsi.ac.id
}

\begin{abstract}
The phenomenon of government financial reports that have not received an unqualified opinion because they have not presented financial information that is following applicable standards and is not transparent and accountable for the management of regional finances, makes the level of trust of users of financial statements doubt the various information presented. The demand for clean governance is also a strong foundation so that the bureaucratic apparatus is able to present quality financial statements. This study aims to understand the effectiveness of the application of the Government Internal Control System (SPIP) and the Regional Management Information System (SIMDA) currently being applied and its impact on the quality of financial statements. The research method used was a survey method. Then the data is collected from the results of questionnaires, interviews and literature studies. Data analysis is descriptive and verification. The results showed that SPIP and SIMDA had a significant impact on the quality of financial statements in Cireunghas District, Sukabumi District.
\end{abstract}

Keywords: financial statements, quality, SIMDA, SPIP

Accepted: 28-10-2020, Revision: 17-01-2021, Published: 01-04-2021

\section{INTRODUCTION}

Currently,

transparency and accountability are important efforts to be made to create good governance as a manifestation of reform. Transparency is the principle of ensuring everyone's freedom of access to information on governance, policy formulation and implementation processes, and results achieved, but this is not required by high-quality local government financial reports, which require every financial manager to fully understand these aspects. financial statements (Muda et al., 2017). If the manager of financial reports does not have good knowledge, it will result in an error in the published financial report which has a negative impact on the report users and the report presenters themselves. The division that manages financial statements must have a good capacity in performance by taking advantage of advances in information technology. As stated by Nasution in (Aditya \& Surjono, 2017), the weaknesses of the Indonesian national financial system, namely:
(1) weaknesses in the design and implementation of the internal control system; (2) non-compliance with laws and regulations; (3) national financial storage that is not in accordance with standards; (4) inadequate information about state-owned assets and liabilities and (5) disclosure of inconsistencies and deficiencies in government financial reports. Increasing transparency and accountability of national financial management, the government has made overall corrections. One of the efforts made was compiling a package of state financial legality, namely Law No. 17 the Year 2003 concerning State Finance, Law No. 01 the Year 2004 concerning State Treasury, and Law No. 15 the Year 2004 concerning Audit of the Management and Accountability of State Finances.

The Government Internal Control System (Sistem Pengendalian Internal Pemerintah/SPIP) is a monitoring tool so that organizational goals and objectives can be achieved and to realize good governance and 
can provide adequate assurance regarding the achievement of operational effectiveness and efficiency, reliability of financial reporting, and compliance with laws and regulations apply which are heavily influenced by human resources (Bulan, Tinangon, \& Mawikere, 2017; Suryatin, Anugerah, \& Indrawati, 2019; Arfiansyah, 2020). It is hoped that the existence of SPIP will improve the quality of financial statements so that financial statements issued by the central or regional governments can be better evaluated. Because with the increase in the good rating given by the BPK on financial statements, it means that the report can be trusted as a decisionmaking tool by interested users. Good practices can also prevent counter-productive activities against the prevailing regulations, thus allowing for effective and efficient action to prevent losses to state finances (BPK, 2014).

Another factor affecting the quality of local government financial reports is the implementation of the Regional Management Information System (Sistem Informasi Manajemen Daerah/SIMDA). SIMDA was made by the Financial and Development Supervisory Agency (BPKP) as a system of information for the development and implementation of the performance-based regional budget (APBD) preparation process.

BPKP in accordance with its function as an internal government auditor and as the bearer and operator of SPIP by Government Regulations No. 60 Year 2008 developed the SIMDA financial application from statutory provisions and local government financial management regulations based on Regulation of the Minister of Home Affairs (Permendagri) No. 13 Year 2006 concerning Guidelines for Regional Financial Management (U. Dewi, Firdaus, \& Saptomo, 2017).

The main objective of the SIMDA financial application is to produce financial statements and financial information in a timely, complete, accurate and reliable manner in accordance with applicable regulations, and to promote the realization of a regional financial management system based on good governance and regional financial management. by providing information technology (Dewi, Novia Citra; Mariska, 2018).

Based on the description above, the focus of this research is whether the Government's Internal Control System (SPIP) has an impact on the quality of financial reports and whether the implementation of the Regional Management Information System (SIMDA) has an impact on the quality of financial statements.

The quality of government financial reports is very important because it is a prerequisite for good governance. One way to meet the classification of good governance in shaping the quality of financial statements is to implement a regional financial management accountability system through SPIP and SIMDA.

\section{LITERATURE REVIEW \\ Government Internal Control System (SPIP)}

Referring to Government Regulations No. 60 the Year 2008 on the Government Internal Control System, (Martini, 2019) shortly explain that SPIP is a leadership activity and all employees continue to take complete action and process activities through effective and efficient financial reporting and asset security activities in accordance with applicable regulations, and provide sufficient confidence to achieve organizational goals. Good inspection and choice of internal system standards will provide protection against human weakness and reduce the possibility of errors and irregularities (Riyanto, 2015).

(Martini, 2019) also explains the elements of SPIP which include: 1) the control environment ; 2) risk assessment; 3) control activities; 4) information and communication, and; 5) internal control monitoring.

SPIP is a systematic arrangement and framework that provides protection for various units of assets and other assets that can be used by the organization, then confirms the correct and reliable financial statements, principles or legal and control measures to increase consistent progress, and to complement productivity and task success (N. F. Dewi, Ferdous Azam, \& Yusoff, 2019). 


\section{Regional Management Information System (SIMDA)}

SIMDA is an application that helps subdistrict officials manage and provide comprehensive and accurate financial information to stakeholders (Sugiyantari, Titisari, \& Sumani, 2018).

The SIMDA financial application database can make financial management more effective and efficient and the SIMDA application can be accessed from anywhere as long as it is connected to the internet. The data entered is directly encrypted, so as to prevent wiretapping and being accessed in real-time, that is, when a stakeholder wants to view a report, he or she can immediately access it and provide accurate information. An effective information system can provide users with accurate, timely, and relevant information (Sugiyantari et al., 2018). In addition to the above definition, SIMDA is also defined as an integrated application used as a tool by the Regional Financial and Asset Management Agency in carrying out financial management activities so that it is able to produce local government financial reports (Sugiyantari et al., 2018).

\section{Quality of Financial Statements}

Financial statements according to Government Regulation No. 71 the Year 2010 in accordance with Government Accounting Standards in (Wulandari, 2018) states that financial reports are structured reports on financial status and transactions carried out by reporting entities. Specifically, the purpose of financial reporting by the public sector (Wulandari, 2018) is: 1) providing information about resources, allocate and use financial resources; 2) provide information about how entities finance their activities and meet cash needs; 3 ) provide information that is useful for assessing the ability of an entity to finance its activities and fulfill its obligations and commitments; 4) provide information about the entity's financial situation and changes; 5) provide general information that helps evaluate the entity's performance in relation to costs.

According to (Wulandari, 2018) the quality characteristics of financial statements must refer to Government Regulation No. 71 the Year 2010 which emphasizes: 1) relevant, the information contained in it can influence user decisions by helping users evaluate past or current events, predict the future, and confirm or improve the results of their past evaluations; 2) reliable, information in the financial statements is free from misleading concepts and major errors, and every fact can be honestly stated and verified; 3) can be compared, comparing it with previous period financial statements, the information contained in the financial statements will be more useful, and; 4) understandably, users can understand the information displayed in the financial statements and disclose it in terms that are in accordance with the user's understanding.

Local government financial statements are not to meet the specific needs of each user group but by improving the quality of local government financial statements of course by understanding SPIP and utilizing SIMDA. Understanding SPIP by understanding the accounting process until it becomes a financial statement that is prepared based on the principles and standards for preparing statements as stipulated in Government Regulation No. 71 the Year 2010 concerning Government Accounting Standards (GAS). When making high-quality financial statements, employees must carefully consider the quality in completing the preparation of financial statements, that is, the personnel participating in this activity must understand how to apply accounting and implementation procedures in government in accordance with applicable regulations. This is in line with the results of research (Rafid, 2016) which states that the GAS has a significant effect on the quality of local government financial statements. Local financial information systems can assist in presenting and improving the quality of government financial statements. If the quality of the information system runs well, all processes will run smoothly, so that it can produce good quality financial statements. Information technology network facilities specially designed for financial statement preparation will reduce the error rate in accounts and save time in the preparation process. In line with the research, (Aulina Nur, 2019) argues that the use of a 
regional financial information system has a simultaneous effect on the quality of local government financial statements.

The framework for the discussion of the literature above can be described as follows:

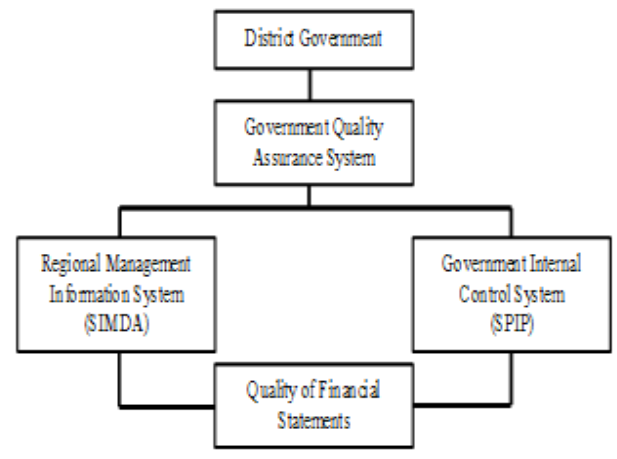

Source: Primary data processed, 2020.

Figure 1. Framework

The research paradigm used in this study is the dual paradigm with two variables because it consists of two independent variables and one dependent variable. This can be described as follows:

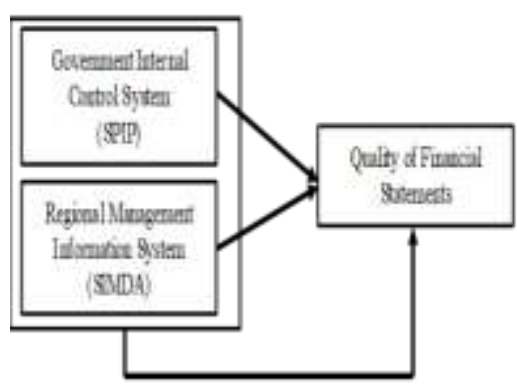

Source: Primary data processed, 2020.

Figure 2. Research Paradigm

Based on the description of the discussion, the hypothesis can be described as follows:

$\mathrm{H} 1$ : SPIP has a positive impact on the quality of financial statements.

$\mathrm{H} 2$ : SIMDA has a positive impact on the quality of financial statements.
H3 : SPIP and SIMDA have a positive impact on the quality of financial statements.

\section{RESEARCH METHODS}

In this research, the method used by this research is the survey method. The survey method is a method for obtaining data from certain natural locations (non-synthetic locations), but researchers will process the data collection by collecting questionnaires, conducting tests, and conducting structured interviews (Sugiyono, 2017). This study uses a descriptive and verification approach. The descriptive method was used to determine SPIP, SIMDA implementation, and the quality of financial statements in Cireunghas District, Sukabumi Regency. The verification method is useful in answering the formulation of problems and the impact of the application of SPIP and SIMDA on the quality of financial statements.

The population is a general area, which consists of objects or topics with specific characteristics, and researchers determine the characteristics to be studied and then draw conclusions. Based on the title taken the effectiveness of the implementation of SPIP and SIMDA and its impact on the quality of financial statements, the population in this study is Cireunghas District, Sukabumi Regency, which consists of 5 villages, namely:

Table 1. Population Distribution

\begin{tabular}{cl}
\hline No & \multicolumn{1}{c}{ Village } \\
\hline $\mathbf{1}$ & Cipurut \\
\hline $\mathbf{2}$ & Bencoy \\
\hline $\mathbf{3}$ & Cikurutug \\
\hline $\mathbf{4}$ & Cireunghas \\
\hline $\mathbf{5}$ & Tegalpanjang \\
\hline
\end{tabular}

Source: Primary data processed, 2020.

The sampling technique uses probability sampling. The type of probability sampling used in this study is simple random sampling. It is said to be simple because the sampling of members from the population is done randomly without paying attention to the strata in the population. This method is done 
when members of the population are considered homogeneous (Sugiyono, 2017).

The population was 47 people consisting of members of village government administrators who were taken from Bencoy Village, Cireunghas Village, Cipurut Village, Tegalpanjang Village and Cikurutug Village, Cireunghas District, Sukabumi Regency. Determination of taking the number of samples if less than 100 is better taken all (Schreiber \& Asner-Self, 2011; Nazir, 2014), then it was decided that the entire population of 47 people was designated as the research sample.

Testing the validity of using the construct validity. After the data was compiled, the construct validity was tested with item analysis, where the item scores were correlated with the total score. Then the formula used to correlate each item of the instrument is by using the Product Moment correlation.

$$
r x y=\frac{n \sum X Y-\left(\sum X\right)\left(\sum Y\right)}{\sqrt{\left(n \sum X^{2}-\left(\sum X^{2}\right)\left(n \sum Y^{2}-\left(\sum Y^{2}\right)\right]\right.}}
$$

Remarks:

$r_{x y}=$ Coefficient of validity

$\mathrm{n}=$ Number of respondents

$\mathrm{X}=$ Score of one question

$\mathrm{Y}=$ Total score of the question

Standard decision validity $r_{\text {count }} \geq r_{\text {table }}$ means that if the calculation of the validity of the results is more than $r_{\text {table, then the }}$ instrument is said to be valid or has validity and can be used as a data collection tool, but if it is less than the value of $r_{\text {table }}$ then the question item can be used as a tool. data retrieval. The purpose of measuring data reliability is to confirm the consistency of the data collected. Internally consistent reliability testing using coeficient Cronbach Alpha. The reason for using this technique is because the $\alpha$-cronbach coefficient is a fairly perfect index in measuring consistency reliability. The Cronbach's Alpha formula is as follows:

$r=\frac{K}{k-1}\left(1-\frac{\sum S i}{S t}\right)$
Remarks:

r1 = Value of reliability

$\sum \mathrm{Si}=$ Total number of variance score of each item

$\mathrm{Si} \quad=$ Total variance

$\mathrm{K}=$ Number of items measuring reliability indicators

If $\mathrm{r} 1 \geq 0,06$ means that it is declared reliable If $\mathrm{r} 1 \leq 0,06$ means that it is declared unreliable

Data collection using the following techniques: 1) primary data, primary data is carried out by direct survey at the research location to obtain data accountability. The data obtained using research include: interviews, observations and questionnaires; 2) secondary data, secondary data, namely data obtained from the results of literature studies by studying, researching, reviewing and reviewing literature such as previous studies, books, articles and statutory regulations.

The fulfillment of the multiple linear regression test must meet the criteria of the classical assumption test which consists of a normality test and a multicollinearity test. The direction of the normality test is to prove whether in the regression model, the dependent variable and the independent variable have a normal or near-normal distribution in the form of data distribution. Multicollinearity is designed to test whether the regression model finds a correlation between the independent variables (Mustaqim, 2017). If the independent variables are related to each other, these variables are not orthogonal. Orthogonal variables are independent variables, and the relationship between the corresponding independent variables is zero (0) (Meidisa \& Susanti, 2019).

If the researcher intends to predict how the dependent variable is in standard conditions if two or more independent variables are manipulated as predictors (high and low values), the researchers will use multiple regression analysis. The equation form of this multiple linear regression is as follows:

$Y=a+b_{1} X_{1}+b_{2} X_{2}$ 
Remarks:

$\begin{array}{ll}\mathrm{Y} & =\text { Quality of financial reports } \\ \alpha & =\text { Coefficient constant } \\ \mathrm{b}_{1}, \mathrm{~b}_{2} & =\text { Regression coefficient } \\ \mathrm{X}_{1} & =\text { SPIP } \\ \mathrm{X}_{2} & =\text { SIMDA }\end{array}$

Proving the hypothesis using a partial test (t-test). Partial or individual test is used to test whether an independent variable affects the dependent variable.

Hypothesis testing uses a two-party test. The formula used to test the null hypothesis and the alternative hypothesis is rejected or accepted is the t test.

$\frac{r \sqrt{n-2}}{\sqrt{1-r^{2}}}$

Remarks:

$\begin{array}{ll}t & =\text { Correlation test statistics } \\ r & =\text { Correlation coefficient } \\ n & =\text { Number of samples }\end{array}$

The results of the t-test statistical calculations ( $\left.\mathrm{t}_{\text {count }}\right)$ are then compared with the $\mathrm{t}_{\text {table, with }} d k=n-2$ and a significant level of $5 \%(=0.05)$, meaning that if the 0 (zero) hypothesis is rejected with a $95 \%$ confidence level, then the conclusion has $95 \%$ facts, which indicates that there is a (significant) correlation between the two variable. Rejected or not is stated by the following criteria:

1. If $t_{\text {count }}>t_{\text {table, }}$ then $\mathrm{HO}$ is in the rejection area, meaning $\mathrm{Ha}$ is accepted, meaning that there is an influence between SPIP and SIMDA on the quality of financial statements in Cireunghas District, Sukabumi Regency.

2. If $t_{\text {count }}<t_{\text {table, then }} \mathrm{H} 0$ is in the receiving area, meaning $\mathrm{Ha}$ is rejected, meaning that there is no influence between SPIP and SIMDA on the quality of financial statements in Cireunghas District, Sukabumi Regency.

\section{DISCUSSION \\ Validity Test of SPIP (X1)}

The validity test of the SPIP bag was carried out on 19 indicators with sample data (n) of 47 respondents. The validation criterion is if the correlation coefficient is $>0.3$ or equal to 0.3 , then the item is declared valid (Sugiyono, 2017), the number 0.3 is a critical value of data validity with $\alpha 5 \%$. Based on the results of the calculation of the Pearson correlate bivariate analysis, the validity test of the instrument can be seen in the table below:

Table 2. Validity Test Results X1

\begin{tabular}{cccc}
\hline Statement & $\begin{array}{c}\boldsymbol{r} \text { with } \\
\text { Average }\end{array}$ & $\begin{array}{c}\text { Critical } \\
\text { Value }\end{array}$ & Information \\
\hline $\mathbf{1}$ & 0.388 & 0.3 & Valid \\
\hline $\mathbf{2}$ & 0.597 & 0.3 & Valid \\
\hline $\mathbf{4}$ & 0.758 & 0.3 & Valid \\
\hline $\mathbf{5}$ & 0.480 & 0.3 & Valid \\
\hline $\mathbf{6}$ & 0.394 & 0.3 & Valid \\
\hline $\mathbf{7}$ & 0.407 & 0.3 & Valid \\
\hline $\mathbf{8}$ & 0.630 & 0.3 & Valid \\
\hline $\mathbf{9}$ & 0.397 & 0.3 & Valid \\
\hline $\mathbf{1 0}$ & 0.427 & 0.3 & Valid \\
\hline $\mathbf{1 1}$ & 0.615 & 0.3 & Valid \\
\hline $\mathbf{1 2}$ & 0.107 & 0.3 & Invalid \\
\hline $\mathbf{1 3}$ & 0.388 & 0.3 & Valid \\
\hline $\mathbf{1 4}$ & 0.597 & 0.3 & Valid \\
\hline $\mathbf{1 5}$ & 0.758 & 0.3 & Valid \\
\hline $\mathbf{1 6}$ & 0.480 & 0.3 & Valid \\
\hline $\mathbf{1 7}$ & 0.394 & 0.3 & Valid \\
\hline $\mathbf{1 8}$ & 0.407 & 0.3 & Valid \\
\hline $\mathbf{1 9}$ & 0.397 & 0.3 & Valid \\
\hline & 0.427 & 0.3 & Valid \\
\hline
\end{tabular}

Source: Primary data processed, 2020.

The critical value ( $r$ ) is taken from the critical table 0.3 at $\mathrm{n}=47$ and $\alpha 0.05(5 \%)$

Based on the results of the SPIP instrument validity test, the respondent can answer all statement items. The result of 19 indicator statements is declared valid as many as 18 statement items, meaning that only 18 statements can measure what is being measured, namely measuring the validity of the SPIP.

\section{Validity Test of SIMDA (X2)}

The validity test of the SIMDA instrument was carried out on 12 indicators with a data sample (n) of 47 respondents which can be seen in the calculation table. The validation criterion is if the correlation coefficient is $>0.3$, then the item is declared valid, the number 0.3 is a critical value for the validity of the data with $\alpha=5 \%$.

Based on the results of the calculation of the Pearson correlate bivariate analysis, the 
results of the instrument validity test can be seen in the table below:

Table 3. X2 Validity Test Results

\begin{tabular}{cccc}
\hline Statement & $\begin{array}{c}\boldsymbol{r} \text { with } \\
\text { Average }\end{array}$ & $\begin{array}{c}\text { Critical } \\
\text { Value }\end{array}$ & Information \\
\hline $\mathbf{1}$ & 0.571 & 0.3 & Valid \\
\hline $\mathbf{2}$ & 0.687 & 0.3 & Valid \\
\hline $\mathbf{3}$ & 0.732 & 0.3 & Valid \\
\hline $\mathbf{4}$ & 0.686 & 0.3 & Valid \\
\hline $\mathbf{5}$ & 0.536 & 0.3 & Valid \\
\hline $\mathbf{6}$ & 0.587 & 0.3 & Valid \\
\hline $\mathbf{7}$ & 0.571 & 0.3 & Valid \\
\hline $\mathbf{8}$ & 0.687 & 0.3 & Valid \\
\hline $\mathbf{9}$ & 0.732 & 0.3 & Valid \\
\hline $\mathbf{1 0}$ & 0.686 & 0.3 & Valid \\
\hline $\mathbf{1 1}$ & 0.536 & 0.3 & Valid \\
\hline $\mathbf{1 2}$ & 0.587 & 0.3 & Valid \\
\hline
\end{tabular}

Source: Primary data processed, 2020.

The critical value $(r)$ is taken from the critical table 0.3 at $\mathrm{n}=47$ and $\alpha 0.05(5 \%)$.

Based on the results of the SIMDA instrument validity test, the respondent can answer all the statements. The result of the 12 indicator statements is declared valid, meaning that when the 12 statements can measure what you want to measure, namely measuring SIMDA.

\section{Test of the Validity of Financial Statement Quality Instruments (Y)}

Test the validity of the quality instrument the financial statements $(\mathrm{Y})$ consist of 4 dimensions carried out on 10 indicators with sample data (n) of 47 respondents which can be seen in the calculation table. The validation criterion is if the correlation coefficient is $>0.3$, then the item is declared valid, the number 0.3 is a critical value for the validity of the data with $\alpha 5 \%$.

Based on the results of the calculation of the Pearson correlate bivariate analysis, the validity test of the instrument can be seen in the table below:

Table 4. Y Validity Test Results

\begin{tabular}{cccc}
\hline Statement & $\begin{array}{c}\boldsymbol{r} \text { with } \\
\text { Average }\end{array}$ & $\begin{array}{c}\text { Critical } \\
\text { Value }\end{array}$ & Information \\
\hline $\mathbf{1}$ & 0.629 & 0.3 & Valid \\
\hline $\mathbf{2}$ & 0.620 & 0.3 & Valid \\
\hline $\mathbf{3}$ & 0.686 & 0.3 & Valid \\
\hline
\end{tabular}

\begin{tabular}{cccc}
\hline $\mathbf{4}$ & 0.679 & 0.3 & Valid \\
\hline $\mathbf{5}$ & 0.540 & 0.3 & Valid \\
\hline $\mathbf{6}$ & 0.409 & 0.3 & Valid \\
\hline $\mathbf{7}$ & 0.483 & 0.3 & Valid \\
\hline $\mathbf{8}$ & 0.527 & 0.3 & Valid \\
\hline $\mathbf{9}$ & 0.483 & 0.3 & Valid \\
\hline $\mathbf{1 0}$ & 0.168 & 0.3 & Valid \\
\hline
\end{tabular}

Source: Primary data processed, 2020.

The critical value $(r)$ is taken from the critical table 0.3 at $n=47$ and $\alpha 0.05(5 \%)$.

Based on the results of the validity test of the financial statement quality instrument, the respondent can answer all the statements. Where the results of the indicator statements are declared valid as many as 10 , meaning that only 10 indicator statements can measure what you want to measure, namely measuring the quality of financial statements.

\section{Reliability Test X1, X2 and Y}

The results of the reliability test on the research variables are shown in the following table:

Table 5. Reliability Test Results X1, X2 and $\mathrm{Y}$

\begin{tabular}{cc}
\hline Variable & Alpha Cronbach's \\
\hline SPIP (X1) & 0.690 \\
\hline SIMDA (X2) & 0.694 \\
\hline $\begin{array}{c}\text { Financial Statements } \\
\text { Quality (Y) }\end{array}$ & 0.725 \\
\hline
\end{tabular}

Source: Primary data processed, 2020.

At $\mathrm{n}=47$ and $\alpha 0.05(5 \%)$.

Based on table 5 the reliability value of the SPIP variable from 19 statement items, then corrections are made or after dropping 1 invalid statement is made so that it becomes 18 statement items and the value is obtained Alpha Cronbach's $(\alpha)$ of 0.690 means that the value is between $0.600<\alpha>0.800$ which means that the SPIP variable instrument is quite reliable, meaning that it can be trusted as a tool to collect data or respondent's answers that are consistent and uniform. Rated reliability variable SIMDA than 12 items a statement obtained by the value of Alpha Cronbachs $(\alpha)$ of 0.690 means that the value of a reliable be between $0.600<\alpha>0.800$ which means that the SIMDA variable 
instrument is quite reliable, meaning that it can be trusted as a tool to collect data or respondent's answers that are consistent and uniform. Then from the reliability value of the financial statement quality variable from the 10 statement items, it was obtained Cronbach's Alpha value $(\alpha)$ of 0.725 , meaning that the reliable value was between $0.600<\alpha$ $>0.800$, which means that the variable instrument of financial statement quality was quite reliable, meaning that it could be trusted as a tool for collecting data or consistent and uniform respondent answers.

\section{Classic Assumption Test}

The normality test in this study uses a probability-plot (P-Plot) graph and the Kolmogorov-Smirnov Test whose results are displayed in the following graph :

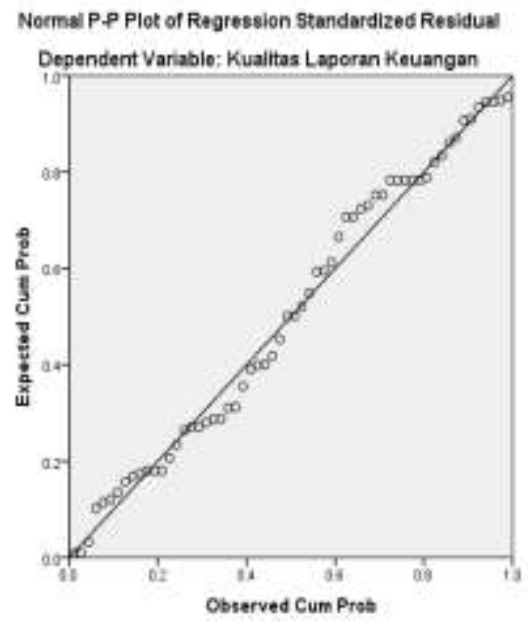

Figure 3. Probability-Plot (P-Plot ) Graph

Based on the appearance of the curve or normal graph of the plot above, it can be concluded that the Histogram graph provides a normal distribution pattern. Meanwhile, the normal P-P plot of regression standardized residual graph shows the dots spread around the diagonal line and the spread follows the diagonal line. So it can be concluded that this graph shows that the regression model is feasible to use because it meets the assumption of normality. Based on the calculation of the Kolmogorov-Smirnov Test for Asymp. Sig. (2-tailed) is obtained by a significance value (p) of 0.200 or $0.200>$ 0.05 , so based on the NPar Test 1-sample KS can say that the data used is normally distributed.

Multicollinearity is designed to test whether the regression model finds a correlation between the independent variables. If the independent variables are correlated, then these variables is not orthogonal. Orthogonal variables are independent variables in which the correlation value between independent variables is equal to zero. The results of the multicollinearity test are shown in the following table:

Table 6. Multicollinearity Test Results

\begin{tabular}{ccc}
\hline Variable & Tolerance & VIF \\
\hline SPIP $(\mathrm{X} 1)$ & 0.566 & 1.766 \\
\hline SIMDA $(\mathrm{X} 2)$ & 0.566 & 1.766 \\
\hline
\end{tabular}

Source: Primary data processed, 2020.

Based on the test results table multicollinearity, the correlation between the independent variable value is lower than 0.90 , then the views of the value of tolerance are variable SPIP $(\mathrm{X} 1)=0.566$ and SIMDA $(\mathrm{X} 2)=0.566$ is greater than 0.10 (tolerance > $0.10)$, this indicates that in this study there were no problems in the multicollinearity test. Likewise, the VIF value of the SPIP variable $(X 1)=1.766$ and SIMDA $(X 2)=1.766$ smaller than 10.00 (VIP<10.00), it can be concluded that there is no multicollinearity between the independent variables in the regression model.

\section{Result of Correlation Test and Coefficient of Determination}

The correlation between SPIP and SIMDA on the quality of financial statements was analyzed using the Pearson correlation method. Meanwhile, the amount of contribution from SPIP and SIMDA to the quality of financial statements was analyzed using the Coefficient of Determination (CD) method 
Table 7. Results Correlation and Coefficient of Determination

\begin{tabular}{|c|c|c|c|c|}
\hline \multicolumn{5}{|c|}{ Correlations } \\
\hline & & $\begin{array}{l}\text { Qualit } \\
\text { y of } \\
\text { Finan } \\
\text { cial } \\
\text { State } \\
\text { ments }\end{array}$ & SPIP & $\begin{array}{c}\text { SIMD } \\
\text { A }\end{array}$ \\
\hline \multirow[t]{3}{*}{$\begin{array}{l}\text { Pea } \\
\text { rso } \\
\mathrm{n} \\
\text { Cor } \\
\text { rela } \\
\text { tio } \\
\mathrm{n}\end{array}$} & $\begin{array}{l}\text { Quality } \\
\text { of } \\
\text { Financia } \\
1 \\
\text { Stateme } \\
\text { nts }\end{array}$ & 1.000 & .655 & .638 \\
\hline & SPIP & .655 & $\begin{array}{r}1.00 \\
0\end{array}$ & .655 \\
\hline & SIMDA & .638 & .638 & 1.000 \\
\hline \multirow[t]{3}{*}{$\begin{array}{l}\text { Sig } \\
\text { (1- } \\
\text { tail } \\
\text { ed) }\end{array}$} & $\begin{array}{l}\text { Quality } \\
\text { of } \\
\text { Financia } \\
1 \\
\text { Stateme } \\
\text { nts }\end{array}$ & & .000 & .000 \\
\hline & SPIP & .000 & & .000 \\
\hline & SIMDA & .000 & .000 & \\
\hline $\mathrm{N}$ & $\begin{array}{l}\text { Quality } \\
\text { of } \\
\text { Financia } \\
1 \\
\text { Stateme } \\
\text { nts }\end{array}$ & 47 & 47 & 47 \\
\hline & SPIP & 47 & 47 & 47 \\
\hline & SIMDA & 47 & 47 & 47 \\
\hline
\end{tabular}

Source: Primary data processed, 2020.

Based on the results of the analysis with the Pearson's correlation test as shown in table 7, then:

1. The correlation value (relationship) of SPIP with the quality of the financial statements is 0.655 which means that it is between the values of $0.600-0.799$, which means that it has a strong and unidirectional relationship. The nature of the relationship is positive, which means that if SPIP increases, the quality of financial statements will increase.

2. The correlation value (relationship) between SIMDA and the quality of financial statements is 0.638 , which means that it is between the values of $0.600-0.799$, which means that it has a strong and unidirectional relationship. The nature of the positive relationship means that if SIMDA increases, the quality of financial statements will get better or increase as well.

Table 8. Results of Correlation Test of SPIP and SIMDA on the Quality of Financial Statements

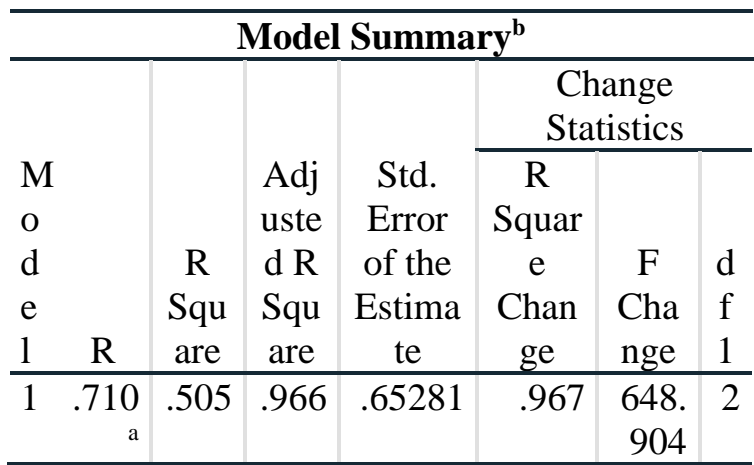

Source: Primary data processed, 2020.

Then to see the effectiveness between SPIP and SIMDA simultaneously (simultaneously) on the quality of financial statements, it can be seen that the magnitude of the correlation value (relationship) between SPIP and SIMDA simultaneously on the quality of financial statements is 0.710 which means it is between the values of 0.600 0.799 , meaning that it has a relationship strong and unidirectional. The nature of the positive relationship illustrates if the SPIP and SIMDA increase or increase, the quality of the financial statements will increase or increase as well.

The value of the coefficient of determination with $\mathrm{R}$ Square $\left(\mathrm{R}^{2}\right)$ based on table 7 can be calculated as follows:

$\mathrm{CD}=(0.710)^{2} \times 100 \%$

$\mathrm{CD}=0.505 \times 100 \%$

$\mathrm{CD}=50.5 \%$

Based on the above calculations, it can be seen that the coefficient of determination is 0.505 or $50.5 \%$. This means that SPIP and SIMDA simultaneously contributed $50.5 \%$ to the quality of financial statements and the remaining $49.5 \%$ was influenced by other 
variables such as information technology, work environment, honesty, accountability, transparency, regulations and so on.

\section{Multiple Linear Regression Test Results}

The results of testing and multiple linear regression analysis are shown in the following table:

Table 9. Multiple Linear Regression Test Results

\begin{tabular}{|c|c|c|c|c|c|}
\hline \multicolumn{6}{|c|}{ Coefficients $^{\mathrm{a}}$} \\
\hline \multirow[b]{2}{*}{ Model } & \multicolumn{2}{|c|}{$\begin{array}{l}\text { Unstandardize } \\
\text { d Coefficients }\end{array}$} & \multirow{2}{*}{$\begin{array}{c}\text { Stan } \\
\text { dardi } \\
\text { zed } \\
\text { Coef } \\
\text { ficie } \\
\text { nts } \\
\\
\text { Beta }\end{array}$} & \multirow[b]{2}{*}{$\mathrm{t}$} & \multirow[b]{2}{*}{ Sig. } \\
\hline & B & $\begin{array}{l}\text { Std. } \\
\text { Error }\end{array}$ & & & \\
\hline $\begin{array}{ll}1 \text { (Const } \\
\text { ant) }\end{array}$ & $\begin{array}{r}12.80 \\
9 \\
\end{array}$ & 1.164 & & 2.813 & .007 \\
\hline SPIP & .541 & .058 & .322 & 5.820 & .000 \\
\hline $\begin{array}{l}\text { SIMD } \\
\text { A }\end{array}$ & .581 & .095 & $\begin{array}{r}1.29 \\
1\end{array}$ & 5.559 & .000 \\
\hline
\end{tabular}

Source: Primary data processed, 2020.

Based on the output of table 9 above, the constant is 12.809, the regression coefficient value for SPIP is 0.541 and SIMDA is 0.581 , thus the regression equation can be written:

$$
\begin{gathered}
\mathrm{Y}=12.809+0.541 \mathrm{X}_{1}+0.581 \mathrm{X}_{2} \\
\mathrm{Y}=13.951
\end{gathered}
$$

The regression equation can be translated:

1. The constant has a value of 12.809 , which states that if the SPIP and SIMDA do not increase or equal to a value of 0 (zero), then the value of the quality of financial statements is 12.809

2.Regression coefficient value SPIP of 0.541 and is positive, meaning that if the variable SPIP increased by 1 point, - it will cause the value of the quality of financial statements to increase by 0.541 points. This shows that SPIP has a positive or unidirectional relationship with the quality of financial statements.

3.The SIMDA regression coefficient value is
0.581 and is positive, meaning that if the SIMDA variable increases by 1 point, it will cause the value of the quality of financial statements to increase by 0.581 points. This shows that SIMDA has a positive or unidirectional relationship with the quality of financial statements.

\section{Hypothesis Test Results}

Hypothesis testing uses the t-test to determine whether in the regression model the independent variables partially have a significant effect on the dependent variable or not.

Based on table 9 it can also be seen that SPIP has a significance of $0.000<0.05$, which is smaller $(\operatorname{sig}<\alpha)$ with a significant level of 0.05 , and $t_{\text {count }}(t-s t a t)$ of 5.820 . This value is compared with the $t_{\text {table }}$ value in the $t$ distribution table, thus $\alpha=0.05$, df $=\mathrm{n}-(\mathrm{k}-1)$ so that $\mathrm{df}=46$, is obtained, then for the twotailed test the $t_{\text {tabel }}$ value is obtained amounting to 2.013. It is known that $t_{\text {count }}$ for X1 (5.820) $>t_{\text {table }}$ atau $\left(\mathrm{t}_{\text {count }}>\mathrm{t}_{\text {table }}\right)$ and is outside $\mathrm{t}_{\text {table }}(-$ 2.013 and 2.013), then $\mathrm{HO}$ is rejected (H1 accepted). Partially SPIP has a significant effect on the quality of financial statements. This means that if the SPIP increases, the quality of financial reports will also increase.

Based on table 9, it can be seen that SIMDA has a smaller significance of $0.000<$ $0.05(\operatorname{sig}<\alpha)$ with a significant level of 0.05 , and the $t_{\text {count }}(t-s t a t)$ is 5.559 . This value is compared with the $t_{\text {table }}$ value in the $t$ distribution table, thus $\alpha=0.05$, $\mathrm{df}=\mathrm{n}-(\mathrm{k}-1)$ so that $\mathrm{df}=46$ is obtained, then for the twotailed test, the $t_{\text {table }}$ value is obtained. amounting to 2.013. It is known that $t_{\text {count }}$ for $\mathrm{X} 2(5.559)>\mathrm{t}_{\text {table }}$ or $\left(\mathrm{t}_{\text {count }}>\mathrm{t}_{\text {table }}\right)$ and is outside the $\mathrm{t}_{\text {table }}(-2.013$ and 2.013), then $\mathrm{H} 0$ is rejected (H2 is accepted). SIMDA partially has a significant effect on the quality of financial statements. This means that if SIMDA increases, it will have an impact on improving the quality of financial statements. 
Table 10. F Test Results

\begin{tabular}{|c|c|c|c|c|c|}
\hline \multicolumn{6}{|c|}{$\mathrm{ANOVA}^{\mathrm{a}}$} \\
\hline Model & $\begin{array}{c}\text { Sum } \\
\text { of } \\
\text { Squ } \\
\text { ares }\end{array}$ & df & $\begin{array}{c}\text { Mea } \\
\text { n } \\
\text { Squa } \\
\text { re }\end{array}$ & F & Sig. \\
\hline $\begin{array}{ll}1 & \text { Regr } \\
\text { essio } \\
n\end{array}$ & $\begin{array}{r}553 . \\
079\end{array}$ & 2 & $\begin{array}{r}276 . \\
539\end{array}$ & 22.425 & $.000^{\mathrm{b}}$ \\
\hline $\begin{array}{l}\text { Resid } \\
\text { ual } \\
\end{array}$ & $\begin{array}{r}8.7 \\
51 \\
\end{array}$ & 44 & .426 & & \\
\hline Total & $\begin{array}{c}571 . \\
830\end{array}$ & 46 & & & \\
\hline
\end{tabular}

Source: Primary data processed, 2020.

The results of the $\mathrm{F}$ test are based on table 10, it can be seen that the significance of $0.000<0.05$ and the $F_{\text {count }}(\mathrm{F}$-stat) is 22.425 . This value is compared with the value of $\mathrm{F}_{\text {table }}$ on the $\mathrm{F}$ distribution table, thus $\alpha=0.05, \mathrm{df}=$ $\mathrm{n}(\mathrm{k}-1)$ thus obtained $\mathrm{df}=46$, then for a twosided test (two-tailed) obtained $\mathrm{F}_{\text {table }}$ for 3.20. It is known that $F_{\text {count }}(22.425)>F_{\text {table }}(3.20)$ or $\mathrm{F}_{\text {count }}>\mathrm{F}_{\text {table, }}$ so $\mathrm{H} 0$ is rejected $(\mathrm{H} 1$ accepted). This means that SPIP and SIMDA simultaneously have an impact on the quality of financial statements.

\section{CONCLUSION}

The results of the discussion and analysis of data that have been tested can be concluded that the effectiveness of SPIP and SIMDA together can improve the quality of financial statements and in following with the criteria established according to Government Regulation No. 71 the Year 2010 concerning Governmental Accounting Standards, including relevant, reliable, compared and understandable.

Recommendations for research that would come to be developed and focus on accountability and transparency of data more extensively in the area of financial reporting, so that the study produced better, concrete, and comprehensive.

\section{REFERENCE}

Aditya, O. R., \& Surjono, W. (2017). Pengaruh Sistem Pengendalian Intern Terhadap Kualitas Laporan Keuangan.
Jurnal SIKAP (Sistem Informasi, Keuangan, Auditing Dan Perpajakan), 2(1), 49. https://doi.org/10.32897/sikap.v2i1.64

Arfiansyah, M. A. (2020). Pengaruh Sistem Keuangan Desa dan Sistem Pengendalian Intern Pemerintah Terhadap Akuntabilitas Pengelolaan Dana Desa. JIFA (Journal of Islamic Finance and Accounting), 3(1), 67-82.

Aulina Nur, R. (2019). Pengaruh Pemahaman Standar Akuntansi Pemerintah, Pemanfaatan Sistem Informasi Keuangan Daerah Dan Kompetensi Sumber Daya Manusia Terhadap Kualitas Laporan Keuangan Pemerintah Kabupaten Serdang Bedagai. Fakultas Ekonomi dan Bisnis Islam Universitas Islam Negeri Sumatera Utara Medan. Universitas Islam Negeri Sumatera Utara.

BPK. (2014). Laporan BPK 2014. Siaran Pers Badan Pemeriksa Keuangan, 3.

Bulan, S. G. I., Tinangon, J., \& Mawikere, L. (2017). Pengaruh Kualitas Pengelola Keuangan dan Sistem Pengendalian Intern Pemerintah (SPIP) terhadap Efektivitas Pengelolaan Keuangan Daerah pada Inspektorat Pemerintah Kota Manado. Going Concern: Jurnal Riset Akuntansi, 12(01), 263-271.

Dewi, Novia Citra; Mariska, S. (2018). Analisis Penerapan Sistem Informasi Manajemen Daerah (SIMDA) Keuangan Pada Pemerintahan Kota Pariaman. Jurnal Lembaga Keuangan Dan Perbankan, 3(1).

Dewi, N. F., Ferdous Azam, S. M., \& Yusoff, S. K. M. (2019). Factors influencing the information quality of local government financial statement and financial accountability. Management Science Letters, $\quad 9(9), \quad$ 1373-1384. https://doi.org/10.5267/j.msl.2019.5.013

Dewi, U., Firdaus, \& Saptomo, P. (2017). Kedudukan Badan Pemeriksa Keuangan Dan Pembangunan (BPKP) Dalam Penentuan Unsur Kerugian Keuangan Negara Dalam Kaitannya Dengan 
Optimalisasi Pengawasan Pengelolaan Keuangan Daerah (Studi Kasus Di Kalimantan Barat). Jurnal Nestor Magister Hukum, 4(4), 209597.

Martini, R. (2019). Sistem Pengendalian Intern Pemerintah Atas Akuntabilitas Pengelolaan Keuangan Dana Desa Di Kecamatan Sembawa. Jurnal Akademi Akuntansi, 2(1), 106-123. https://doi.org/10.22219/jaa.v2i1.8364

Meidisa, C., \& Susanti, F. (2019). Pengaruh Preferensi Dan Pengetahuan Produk Terhadap Minat Menabung Masyarakat Pada Bank Nagari Unit Layanan Syariah Cabang Pasar Raya Padang. https://doi.org/10.31227/osf.io/bf7cr

Muda, I., Wardani, D. Y., Erlina, Maksum, A., Lubis, A. F., Bukit, R., \& Abubakar, E. (2017). The influence of human resources competency and the use of information technology on the quality of local government financial report with regional accounting system as an intervening. Journal of Theoretical and Applied Information Technology, 95(20), 5552-5561.

Mustaqim, R. N. (2017). Analisis FaktorFaktor yang Memengaruhi Niat Penggunaan E-Commerce XYZ Menggunakan Model UTAUT (Unified Theory Acceptance and Use Of Technology). Universitas Brawijaya.

Nazir, M. (2014). Metode Penelitian (14th ed.). Bogor: Penerbit Ghalia.

Rafid, R. Z. (2016). Pengaruh Pemahaman Standar Akuntansi Pemerintahan Dan Pemanfaatan Sistem Informasi Akuntansi Terhadap Kualitas Laporan Keuangan Dengan Kompetensi Sumber Daya Manusia Sebagai Variabel Moderasi (Studi Empiris pada Pemerintahan Kabupaten Bone). Fakultas Ekonomi Dan Bisnis Islam Universitas Islam Negeri Alauddin Makassar. Universitas Islam Negeri Alauddin Makassar.

Riyanto, A. (2015). Pengaruh Pemeriksaan Intern Terhadap Efektivitas Pengendalian Intern Atas Persediaan Bahan Baku Pada Pt. Chandra Asri
Petrochemical Jakarta. Ecodemica, 3(1), 405-417.

Schreiber, J., \& Asner-Self, K. (2011). Educational Research. New Jersey: John Wiley \& Sons, Inc.

Sugiyantari, D., Titisari, P., \& Sumani, S. (2018). Efektivitas Implementasi Sistem Informasi Manajemen Daerah (Simda) Keuangan Cloud Pada Pemerintah Kabupaten Jember. Bisma, 12(1), 106. https://doi.org/10.19184/bisma.v12i1.76 07

Sugiyono. (2017). Metode Penelitian Kuantitatif Kualitatif dan $R \& D$. Bandung: Alfabeta.

Suryatin, Anugerah, R., \& Indrawati, N. (2019). Pengaruh sumber daya manusia, ketersediaan infrastruktur, komitmen pimpinan, dan keteladanan pimpinan terhadap tingkat maturitas sistem pengendalian intern pemerintah (Studi pada Pemerintah Daerah Kabupaten Indragiri Hulu). Pekbis (Jurnal Pendidikan Ekonomi Dan Bisnis), 11(1), 43-54.

Wulandari, M. (2018). Penerapan Standar Akutansi Pemerintah dan Kopetensi SDM terhadap Laoran Keuangan Pemerintah Daerah degan Komitmen Organisasi sebagai variable modreasi. Fakultas Ekonomi, Universitas Negeri Padang, 1, 16. 